sjme KINEMATIKA VOL.2 NO.1, 1 Juni 2017, 53-65

\title{
PEMBUATAN BIOGAS DENGAN VARIASI STARTER RAGI DAN KOTORAN SAPI BERBAHAN BAKU SAMPAH ORGANIK
}

\author{
Rachmat Subagyo ${ }^{1}$ Roni Wijaya ${ }^{2}$ \\ ${ }^{1,2}$ Program Studi Teknik Mesin Fakultas Teknik Universitas Lambung Mangkurat \\ Jl. Akhmad Yani Km. 36 Banjarbaru, Kalimantan Selatan, 70714 \\ Telp. 0511-4772646, Fax 0511-4772646 \\ E-mail: Roniw750@gmail.com ${ }^{1)}$
}

\begin{abstract}
This study aims to determine the composition of the right starter mixture to produce optimal biogas, knowing the temperature (in digester) at the time of fermentation, knowing the effect fungal growth on the levels of biogas. Processing organic waste in small pieces given water and starter, put in bottle and covered with balloon, last process fermentation 45 days. Then samples tested using Methane Measurement System, Carbondioxide, Humidity and Temperature. Then obtained mixture 10\% starter cow dung and 90\% organic waste $\mathrm{CH}_{4} 35.79 \mathrm{ppm}$ and $\mathrm{CO}_{2}$ 1763.34 ppm, 20\% cow dung and 80\% organic waste $\mathrm{CH}_{4} 12.12 \mathrm{ppm}$ and $\mathrm{CO}_{2} 740.55$ ppm, 30\% cow dung and 70\% organic waste, $\mathrm{CH}_{4} 14.08 \mathrm{ppm}$ and $\mathrm{CO}_{2} 858.87 \mathrm{ppm}$, yeast $10 \%$ and organic waste $90 \% \mathrm{CH}_{4} 9.78 \mathrm{ppm}$ and $\mathrm{CO}_{2} 860.98 \mathrm{ppm}, 20 \%$ yeast and $80 \%$ organic waste $\mathrm{CH}_{4} 166.08 \mathrm{ppm}$ and $\mathrm{CO}_{2} 1185.35 \mathrm{ppm}$ and yeast mixture $30 \%$ and $70 \% \mathrm{CH}_{4}$ organic waste $16.66 \mathrm{ppm}$ and $\mathrm{CO}_{2} 927.39 \mathrm{ppm}$. The yeast mixture $20 \%$ and $80 \%$ organic waste produces most optimal $\mathrm{CH}_{4}$ with temperature in digester at fermentation $30.11{ }^{\circ} \mathrm{C}$ with value $206.76 \mathrm{ppm}$ while mixture $10 \%$ cow dung and $90 \%$ organic waste produces highest $\mathrm{CO}_{2}$ at temperature $30.4{ }^{\circ} \mathrm{C}$ with value 2527.57 ppm.
\end{abstract}

Keywords: Organic trash, cow dung, yeast, biogas

\section{PENDAHULUAN}

Pada era globalisasi ini energi merupakan persoalan yang krusial diberbagai belahan dunia. Meningkatnya permintaan energi yang disebabkan oleh pertumbuhan populasi penduduk, menipisnya sumber cadangan minyak serta permasalahan emisi dari bahan bakar fosil. Selain itu, peningkatan harga minyak dunia per barel juga menjadi alasan yang serius yang menimpa banyak negara di dunia salah satu nya Indonesia. Rahman (2005), salah satu alternatif untuk menangani masalah tersebut di atas adalah pemanfaatan sumber daya yang selama ini belum dikelola secara maksimum di Negara ini khususnya dibidang limbah pertanian. Ketersediaan limbah pertanian (biomassa) di Indonesia adalah suatu potensi sumber daya untuk memproduksi energi alternatif terbarukan salah satunya biogas (Sufyandi, 2001).

Biogas adalah salah satu jenis energi yang dapat dibuat dari banyak bahan buangan dan limbah sisa, semacam sampah, kotoran ternak, jerami, enceng gondok serta banyak bahan-bahan lainnya lagi. Segala jenis bahan yang dalam istilah kimia termasuk senyawa organik, yang merupakan sisa dan kotoran hewan maupun sisa tanaman, bisa dijadikan bahan biogas (Suriawiria dkk, 2002). Beberapa hal yang menarik dari teknologi biogas adalah kemampuannya untuk membentuk biogas 
dari limbah organik yang jumlahnya berlimpah dan tersedia secara bebas. Variasi dari sifat-sifat biokimia menyebabkan produksi biogas juga bervariasi. Sejumlah bahan organik dapat digunakan bersama-sama dengan beberapa persyaratan produksi gas atau pertumbuhan normal bakteri metanyang sesua. Beberapa sifat bahan organik tersebut mempunyai dampak/pengaruh yang nyata pada tingkat produksi biogas (Wahyuni, 2011).

Sampah organik yang ada di Indonesia merupakan yang terluas di dunia. Limbah dari sampah organik ini apabila tidak dikelola dengan baik akan merusak lingkungan, terutama daerah aliran sungai dan akan menyebabkan bau yang sangat menyengat. Sampah organik yang belum banyak dimanfaatkan sampai saat ini, sehingga banyak yang dibuang begitu saja sebagai limbah.

Selama ini sampah rumah tangga sulit diolah karena komposisinya banyak dan beragam, sampah rumah tangga terbagi dua yaitu sampah organik dan sampah anorganik, sampah anorganik pada umumnya di daur ulang sedangkan sampah organik sebagian bisa di daur ulang (plastik) sebagian lainnya dapat dijadikan pupuk organik dan bahan bakar. Dalam penelitian ini kami akan mencoba memanfaatkan sampah organik menjadi bahan bakar alternatif (biogas) sampah yang bisa dimanfaatkan adalah sayur-sayuran seperti wortel, kol, dan lain sebagainya. Hasil penelitian menyatakan bahwasannya berbagai jenis limbah dapat digunakan sebagai bahan baku biogas contohnya limbah perkebunan seperti kulit kakao (Lateng, 2010).

Limbah peternakan seperti kotoran sapi dan kotoran ayam dapat digunakan sebagai bahan baku biogas, kotoran sapi mengandung unsur $\mathrm{N} 26,2 \mathrm{~kg} / \mathrm{ton}, \mathrm{P} 4,5$ $\mathrm{kg} / \mathrm{ton}$, dan $\mathrm{K} 13,0 \mathrm{~kg} / \mathrm{ton}$ sedangkan kotoran ayam mengandung sisa pakan dan serat selulosa yang tidak dicerna,protein, karbohidrat, lemak dan senyawa organik lainnya. Protein pada kotoran ayam merupakan sumber nitrogen selain ada pula bentuk nitrogen inorganik lainnya (Foot et al., 1976). Penelitian ini dilakukan untuk mengetahui efektivitas jenis starter kotoran sapi dan ragi untuk menghasilkan biogas dari limbah sampah organik, mengetahui jumlah starter yang tepat untuk menghasilkan biogas dari limbah sampah organik dan mengetahui serta menganalisis waktu fermentasi optimum yang diperlukan untuk menghasilkan biogas.

Biogas adalah campuran gas-gas dari biomassa (bahan-bahan organik) termasuk diantaranya kotoran manusia dan hewan, limbah organik (rumah tangga), sampah biodegradable yang mudah terbakar dan dihasilkan dengan mendayagunakan bakteri melalui proses fermentasi bahan organik dalam keadaan tanpa oksigen atau kedap udara (anaerob) (Harahap, 1980). Komponen biogas adalah metan sebesar $\pm 60 \%$, karbondioksida $\pm 38 \%$, dan $\pm 2 \% \mathrm{~N}_{2}, \mathrm{O}_{2}, \mathrm{H}_{2}$, dan $\mathrm{H}_{2} \mathrm{~S}$. Biogas dapat dibakar seperti elpiji dan dalam skala besar biogas dapat digunakan sebagai pembangkit energi listrik sehingga dapat digunakan sebagai sumber energi alternatif yang ramah lingkungan dan terbarukan (Said, 2006).

Biogas sebenarny adalah gas metana $\left(\mathrm{CH}_{4}\right)$. Gas metana bersifat tidak berbau, tidak berwarna dan sangat mudah terbakar (Dewanto, 2008) juga dalam pengapian berwarna biru (Simamora, 2004). Biogas mempunyai komposisi yang bervariasi tergantung asal proses anaerob yang terjadi (Simamora, 2004). Nilai kalori gas metana murni $8.900 \mathrm{kkal} / \mathrm{m}^{3}$, sedangkan nilai kalor biogas yang masih berupa 
campuran gas-gas berkisar 5.000-6.513 kkal/ $\mathrm{m}^{3}$. Dalam penelitian ini bahan-bahan yang digunakan adalah sampah organik

Kotoran sapi adalah substrat yang dianggap paling cocok sebagai sumber pembuat gas bio, karena substrat tersebut sudah mengandung bakteri penghasil gas metan yang terdapat di dalam perut hewan ruminansia. Keberadaan bakteri di dalam usus besar ruminansia tersebut membantu proses fermentasi, sehingga proses pembentukan gas bio dalam tangki pencerna bisa dilakukan lebih cepat. Walaupun demikian, apabila kotoran tersebut ingin langsung diproses dalam tangki pencerna, perlu dilakukan pembersihan terlebih dahulu. Menurut Dwi Irawan dalam jurnal nya menjelaskan karakteristik kotoran sapi adalah total padatan sebesar 3-6\%, total padatan volatil (mudah menguap) $80-90 \%$, total nitrogen $2-4 \%$, selulosa $15-20 \%$, lignin $5-10 \%$, hemiselulosa $20-25 \%$. Sedangkan untuk starter yang lain nya penulis menggunakan ragi.

Ragi ialah suatu macam tumbuh-tumbuhan bersel satu yang mana tergolong kedalam keluarga cendawan. Ragi (yeast) merupakan fungi yang tidak mempunyai kemampuan membentuk miselium dan pada tahap tertentu di dalam siklus kehidupannya berbentuk sel-sel tunggal yang bereproduksi dengan buah (budding) atau pemecahan (fission). Banyak di antara ragi yang berasal dari mikroba jenis Saccharomyces Cerevisiae. Ragi adalah suatu bahan yang dapat memproduksi gas karbondioksida $\left(\mathrm{CO}_{2}\right)$. Setelah mengetahui penjelasan tentang bahan baku dan starter yang digunakan, selanjutnya akan dibahas tentang perombakan anaerob pada penelitian ini.

Pada saat proses perombakan anaerob terjadi perombakan bahan organik menjadi senyawa dengan berat molekul rendah (gas metana, asam organik, asam asetat, asam propionat, asam butirat, dan asam laktat). Pemanfaatan limbah cair industri tahu dengan penerapan teknologi bersih lewat pengembangan proses perombakan anaerob substrat hasil perombakan bakteri metanogen. Perombakan anaerob adalah proses sederhana, secaranteknologi membutuhkan energi rendah guna mengubah bahan organik dari berbagai jenis air limbah, buangan padat dan biomasa menjadi metana. Tahap-tahap pembuatan biogas dari limbah organik akan dijelaskan sebagai berikut:

(Maramba, 1978).

Pada tahap hidrolisis, mikrobia hidrolitik mendegradasi senyawa organik komplek yang berupa polimer menjadi monomernya yang berupa senyawa yang tidak larut dengan berat molekul yang lebih rendah. Lipid berubah menjadi asam lemak rantai panjang dan gliserin, polisakarida menjadi gula (mono dan disakarida), protein menjadi asam amino, dan asam nukleat menjadi purin dan pirimidin. Proses hidrolisis membutuhkan mediasi exoenzim yang diekskresi oleh bakteri fermentatif. Hidrolisis molekul kompleks dikatalisasi oleh enzim ekstraseluler seperti selulase, protease, dan lipase. Walaupun demikian, proses penguraian anaerob begitu lambat dan sangat terbatas dalam menguraikan limbah selulotik yang mengandung lignin.

Monomer-monomer hasil hidrolisis selanjutnya dirubah menjadi senyawasenyawa organik sederhana diantara nya asam lemak volatil, alkohol, asam laktat, senyawa-senyawa mineral diantaranya karbondioksida, hidrogen, amoniak, dan gas hidrogen sulfida. Tahap ini dikerjakan oleh berbagai kelompok bakteri, yang mayoritas adalah bakteri obligat anaerob dan sebagian dari bakteria anaerob fakultatif. 
Hasil asidogenesis diubah menjadi hasil akhir untuk produksi metana yang berupa asam asetat, hidrogen, dan karbondioksida. Pembentukan asam asetat biasanya disertai dengan pembentukan gas karbondioksida atau hidrogen, ini bergantung pada kondisi oksidasi dari bahan organik aslinya.

Pada tahapan metanogenesis terbentuklah metana dan karbondioksida. Metana dihasilkan dari asetat atau reaksi reduksi karbondioksida oleh bakteri asetotropik dan hidrogenotropik yaitu dengan menggunakan hidrogen.

Reaksi kimia pembentukan metana dari asam asetat dan reduksi $\mathrm{CO}_{2}$ bisa dilihat pada persamaan reaksi sebagai berikut: Asetotropik metanogenesis:

Hidrogenotropik metanogenesis:

$$
\mathrm{CH}_{3} \mathrm{COOH}--->\mathrm{CH}_{4}+\mathrm{CO}_{2}
$$

$$
4 \mathrm{H}_{2}+\mathrm{CO}_{2}--->\mathrm{CH}_{4}+2 \mathrm{H}_{2} \mathrm{O}
$$

Tiga tahapan di atas disebut sebagai fermentasi asam dan untuk tahap keempat disebut fermentasi metanogenesis. Berbagai studi tentang digesti anaerob pada berbagai ekosistem menunjukkan bahwa $70 \%$ atau lebih metana yang terbentuk diperoleh dari asetat (pers.1.1). Asetat merupakan intermediet kunci seluruh fermentasi pada berbagai ekosistem tersebut. Hanya sekitar $30 \%$ bahanbahan organik yang dikonversi menjadi metana melewati jalur hidrogenotropik dari reduksi $\mathrm{CO}_{2}$ menggunakan $\mathrm{H}_{2}$ (pers.1.2).(Maramba, 1978).

\section{METODE PENELITIAN}

\section{2a. Alat Dan Bahan Penelitian}

Botol, balon, pisau kecil, timbangan, karet gelang, kayu pengaduk.

Sampah organik yang dipakai merupakan sampah pasar yang di peroleh dari pasar tradisional Banjarbaru, sedangkan kotoran sapi yang dipakai merupakan kotoran sapi yang sudah dipakai sebelumnya pada pembuatan biogas di daerah Tambang Ulang, Bati-bati dan untuk ragi nya adalah (Saccharomeyces Cereviseae) fermipan.

\section{2b. Pengolahan Bahan}

Menyiapkan limbah organik kemudian limbah organik dicacah kecil-kecil, sampah organik yang sudah dicacah kecil-kecil kemudian dicampur dengan air dipenampung sementara kemudian ditambahkan starter sebanyak 10\%, 20\% dan $30 \%$.

Untuk variabel penelitian di sajikan berikut ini:

Table 2 variabel penelitian

\begin{tabular}{|c|c|c|c|c|c|c|}
\hline \multirow{2}{*}{ No. } & $\begin{array}{c}\text { Jumlah Limbah } \\
\text { Sampah organik } \\
(\text { gram) }\end{array}$ & \multicolumn{3}{|c|}{ Jumlah Perbandingan } & \multirow{2}{*}{$\begin{array}{c}\text { Kadar } \\
\text { Biogas }\end{array}$} \\
\cline { 3 - 6 } & Air (gram) & $\begin{array}{c}\text { Ragi } \\
\text { (gram) }\end{array}$ & $\begin{array}{c}\text { Kotoran sapi } \\
\text { (gram) }\end{array}$ & $\begin{array}{c}\text { Lama Waktu } \\
\text { (hari) }\end{array}$ & \\
\hline 1. & 180 & \pm 200 & 20 & 20 & 45 & A \\
\hline 2. & 160 & \pm 200 & 40 & 40 & 45 & B \\
\hline 3. & 140 & \pm 200 & 60 & 60 & 45 & C \\
\hline
\end{tabular}




\section{2c. Proses Fermentasi}

Siapkan botol untuk fermentasi campuran sampah organik, air dan starter kemudian dimasukkan kedalam botol kemudian ditutup rapat dengan balon dan di ikat dengan karet gelang, setelahnya diam sampel tersebut selama 45 hari.

Untuk memudahkan pengolahan data penelitian ini, maka variabel diberikan symbol sebagai berikut:

Sampel 1: campuran $90 \%$ sampah organik dan $10 \%$ starter kotoran sapi Sampel 2: campuran $80 \%$ sampah orgnaik dan $20 \%$ starter kotoran sapi Sampel 3: campuran 70\% sampah organik dan 30\% starter kotoran sapi Sampel 4: campuran $90 \%$ sampah organik dan $10 \%$ starter ragi Sampel 5: campuran $80 \%$ sampah organik dan $20 \%$ starter ragi Sampel 6: campuran $70 \%$ sampah organik dan $30 \%$ starter ragi

\section{2d. Diagram Alir Penelitian}

Diagram alir pada penelitian ini dapat dilihat pada gambar 1

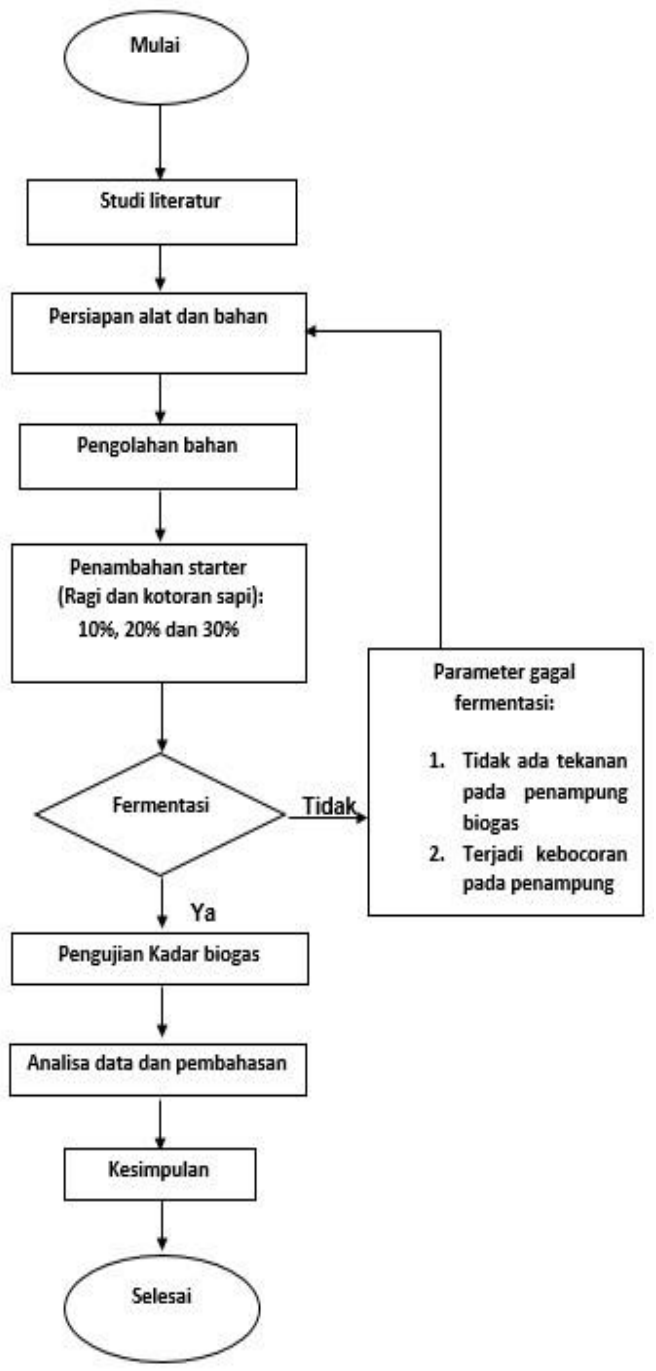

Gambar 1 . Diagram alir penelitian 


\section{HASIL DAN PEMBAHASAN}

Hasil dari proses fermentasi kemudian di uji untuk mengetahui kadar $\mathrm{CH}_{4}$ dan $\mathrm{CO}_{2}$ pada biogas menggunakan alat Sistem Pengukuran Metana $\left(\mathrm{CH}_{4}\right)$, Karbondioksida $\left(\mathrm{CO}_{2}\right)$, Kelembaban dan Temperature di Lab Instrumentasi FMIPA Universitas Lambung Mangkurat sehingga didapat hasil sebagai berikut:

\begin{tabular}{|c|c|c|c|c|c|c|c|}
\hline \multirow[b]{2}{*}{ No. } & \multirow{2}{*}{$\begin{array}{l}\text { Jumlah } \\
\text { Bahan } \\
\text { (gram) }\end{array}$} & \multicolumn{3}{|c|}{ Komposisi Bahan } & \multirow{2}{*}{$\begin{array}{c}\text { Air } \\
\text { (gram) }\end{array}$} & \multirow{2}{*}{$\begin{array}{c}\mathrm{CH}_{4} \\
(\mathrm{ppm})\end{array}$} & \multirow{2}{*}{$\begin{array}{c}\mathrm{CO}_{2} \\
(\mathrm{ppm})\end{array}$} \\
\hline & & $\begin{array}{c}\text { Kotoran } \\
\text { Sapi } \\
\text { (gram) }\end{array}$ & $\begin{array}{c}\text { Ragi } \\
\text { (gram) }\end{array}$ & $\begin{array}{c}\text { Sampah } \\
\text { Organik } \\
\text { (gram) }\end{array}$ & & & \\
\hline \multirow[t]{2}{*}{1.} & 200 & 20 & 0 & 180 & 200 & 37.3 & 1903.07 \\
\hline & 200 & 0 & 20 & 180 & 200 & 10.5 & 892.65 \\
\hline \multirow[t]{2}{*}{2.} & 200 & 40 & 0 & 160 & 200 & 11.99 & 741.34 \\
\hline & 200 & 0 & 40 & 160 & 200 & 171.20 & 131.7 \\
\hline \multirow[t]{2}{*}{3.} & 200 & 60 & 0 & 140 & 200 & 13.40 & 854.33 \\
\hline & 200 & 0 & 60 & 140 & 200 & 16.7 & 928.85 \\
\hline
\end{tabular}

Gambar 2

\section{3a. Grafik Hasil Pengujian $\mathrm{CH}_{4}$ pada Semua Sampel}

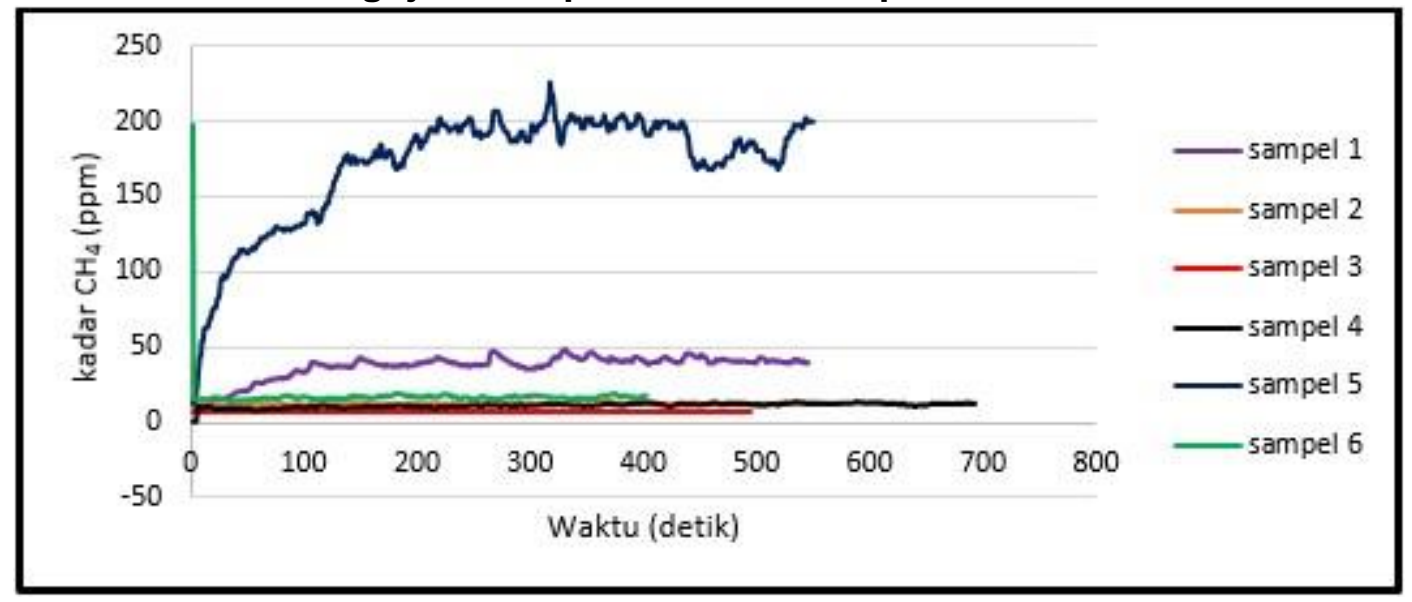

Gambar 3 Grafik $\mathrm{CH}_{4}$ hasil pengujian pada semua sampel

Pada grafik di atas dapat di lihat bahwa kadar biogas untuk $\mathrm{CH}_{4}$ rata-rata memiliki kadar yang cukup rendah, pada sampel 1 (ungu) kadar $\mathrm{CH}_{4}$ masih mengalami kenaikan pada detik-detik awal itu di sebabkan karena sampel yang di hembus kan pada chamber (penampung) masih merambat ke segala arah untuk mengisi ruangruang pada chamber tersebut. Baru lah $\mathrm{CH}_{4}$ atau metana kadar tertinggi nya di capai pada detik ke 330 yaitu sebesar 48,68 (ppm) dan seterus nya mengalami penurunan yang tidak terlalu besar hingga pada akhir pengujian yaitu 40,22 (ppm). Untuk sampel 2 (orange) kadar $\mathrm{CH}_{4}$ pada detik-detik awal tidak mengalami kenaikan yang besar sampai dengan akhir pengambilan data, nilai nya cenderung konstan selama pengambilan data tersebut, hingga pada detik ke 341 titik tertinggi di capai pada nilai 14,83 (pm) dan seterus nya mengalami penurunan sedikit demi sedikit hingga pada akhir penelitian berada pada titik 12,57 (ppm). Pada sampel 3 (merah) untuk kadar $\mathrm{CH}_{4}$ atau metana pada detik awal-awal mengalami keadaan yang cukup konstan hampir sama seperti sampel sebelum nya, pada 
sampel ini titik tertinggi di capai pada detik ke 187 yaitu 30,31 (ppm) dan seterus nya mengalami penurunan namun tidak begitu besar hingga akhir pengambilan data mencapai 11,46 (ppm).

Pada sampel 4 (hitam) untuk kadar $\mathrm{CH}_{4}$ atau metana di awal-awal pengambilan data tidak mengalami kenaikan kadar metana atau cenderung konstan hingga pada detik ke 394 mengalami kenaikan dan mencapai titik tertinggi pada 12,57 (ppm) dan seterus nya mengalami penurunan yang tidak begitu besar hingga akhir pengambilan data yaitu 12,01 (pm). Sedangkan pada sampel 5 (biru tua) mengalami perbedaan dengan sampel yang lain nya, sampel ini merupakan sampel dengan potensi biogas dengan kadar $\mathrm{CH}_{4}$ atau metana paling baik dari sampel yang lain di karena kan jamur tumbuh dengan baik dan pada pengambilan kadar $\mathrm{CH}_{4}$ atau metana meningkat seiring waktu dan mencapai titik tertinggi pada detik ke 267 dengan nilai 206,76 (ppm) dan seterus nya mengalami penurunan yang tidak begitu besar hingga pada akhir pengambilan data mencapai 199,87 (ppm). Dan untuk sampel 6 (hijau) pengambilan data pada sampel ini kadar $\mathrm{CH}_{4}$ atau metana cenderung konstan tidak mengalami kenaikan yang besar di awal-awal pengambilan data hingga pada detik ke 179 mencapai titik tertinggi yaitu 18,39 (ppm) dan seterus nya mengalami penurunan yang tidak begitu besar hingga pada akhir pengambilan data mencapai nilai 17,18 (ppm).

\section{3b. Grafik Hasil Pengujian $\mathrm{CO}_{2}$ pada Semua Sampel}

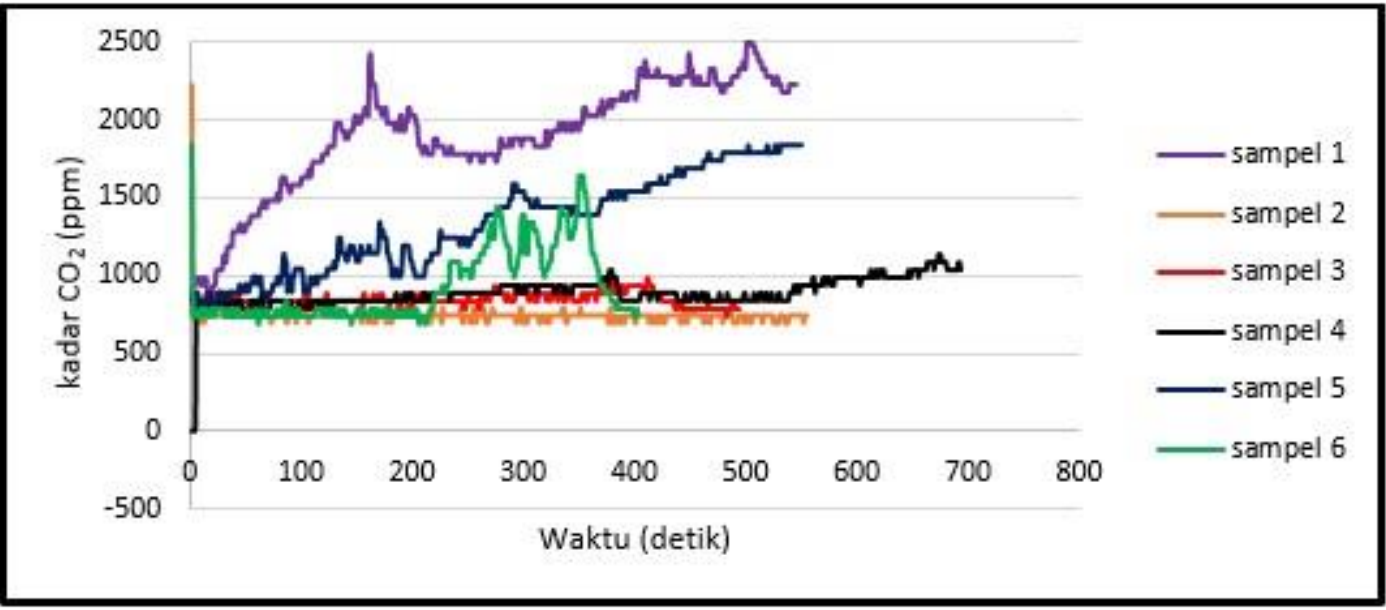

Gambar 4 Grafik $\mathrm{CO}_{2}$ hasil pengujian pada semua sampel

Pada grafik di atas dapat di lihat bahwa kadar biogas untuk $\mathrm{CO}_{2}$ rata-rata memiliki kadar yang cukup tinggi. Pada sampel 1 (ungu) terlihat bahwa kadar biogas yang tercatat pada hasil pengujian menunjukkan peningkatan $\mathrm{CO}_{2}$ seiring waktu, itu di sebabkan sampel yang di hembuskan pada chamber (penampungan) masih mengisi ruang-ruang pada chamber barulah pada detik ke 162 di dapatkan kadar $\mathrm{CO}_{2}$ yang cukup tinggi yaitu 2428,45 (ppm) dan seterus nya mengalami penurunan, selanjutnya mengalami kenaikan kembali dan pada detik ke 502 mengalami kadar tertinggi yaitu sebesar 2527,57 (ppm). Pada sampel 2 (orange) terlihat bahwa kadar biogas yang tercatat berada pada titik yang cukup tinggi di detik-detik awal yaitu 792,96 dan seterus nya mengalami penurunan yang cukup signifikan sampai berada 
pada titik paling rendah yaitu 693,84 (ppm) dan seterusnya mengalami beberapa kali peningkatan dan penurunan kadar $\mathrm{CO}_{2}$, titik tertinggi pada sampel ini berada pada 792,96 (ppm). Untuk sampel 3 (merah) dapat di lihat bahwa kadar $\mathrm{CO}_{2}$ yang tercatat di detik-detik awal sudah mengalami peningkatan namun juga mengalami penurunan dan pada detik ke 384 mencapai titik tertinggi yaitu 941,64 (ppm) dan seterus nya mengalami penurunan hingga mencapai titik terendah dengan nilai 743,4 (ppm).

Pada sampel 4 (hitam) dapat di lihat bahwa kadar biogas yang tercatat tidak mengalami peningkatan yang begitu signikan di detik-detik awal penyebab nya adalah sampel yang di hembuskan ke chamber masih mengisi ruang-ruang pada chamber dan setelah nya pada detik ke $377 \mathrm{CO}_{2}$ mengalami peningkatan yaitu 1040,76 (ppm) lalu mengalami penurunan yang cukup signifikan, barulah pada detik ke 673 mencapai titik tertinggi yaitu 1139,88 (ppm) dan seterus nya mengalami mengalami penurunan yang tidak begitu besar hingga akhir pengambilan data mencapai nilai 1040,76 (ppm). Sedangkan pada sampel 5 (biru tua) dapat di lihat bahwa kadar $\mathrm{CO}_{2}$ meningkat seiring waktu dan pada detik ke 290 mengalami peningkatan kadar $\mathrm{CO}_{2}$ yaitu 1585,92 (ppm) selanjut nya mengalami penurunan cukup signifikan dan baru lah pada detik ke 502 mencapai titik paling tinggi yaitu 1833,72 (ppm) dan seterus nya mengalami sedikit penurunan hingga akhir pengambilan data mengalami peningkatan nilai yang sama dengan titik tertinggi yaitu 1833,72 (ppm). Dan untuk sampel 6 (hijau) dapat di lihat bahwa kadar $\mathrm{CO}_{2}$ yang tercatat pada detik-detik awal tidak mengalami peningkatan yang besar, baru lah pada detik ke 234 kadar $\mathrm{CO}_{2}$ meningkat pada nilai 1090,32 (ppm) dan pada detik ke 350 mencapai titik tertinggi yaitu 1635,48 (ppm) dan seterus nya mengalami penurunan yang cukup besar hingga pada titik 743,4 (ppm).

\section{3c. Perbandingan $\mathrm{CH}_{4}$ Pada Semua Sampel Berdasarkan Pengambilan Data Dengan Waktu Yang Sama}

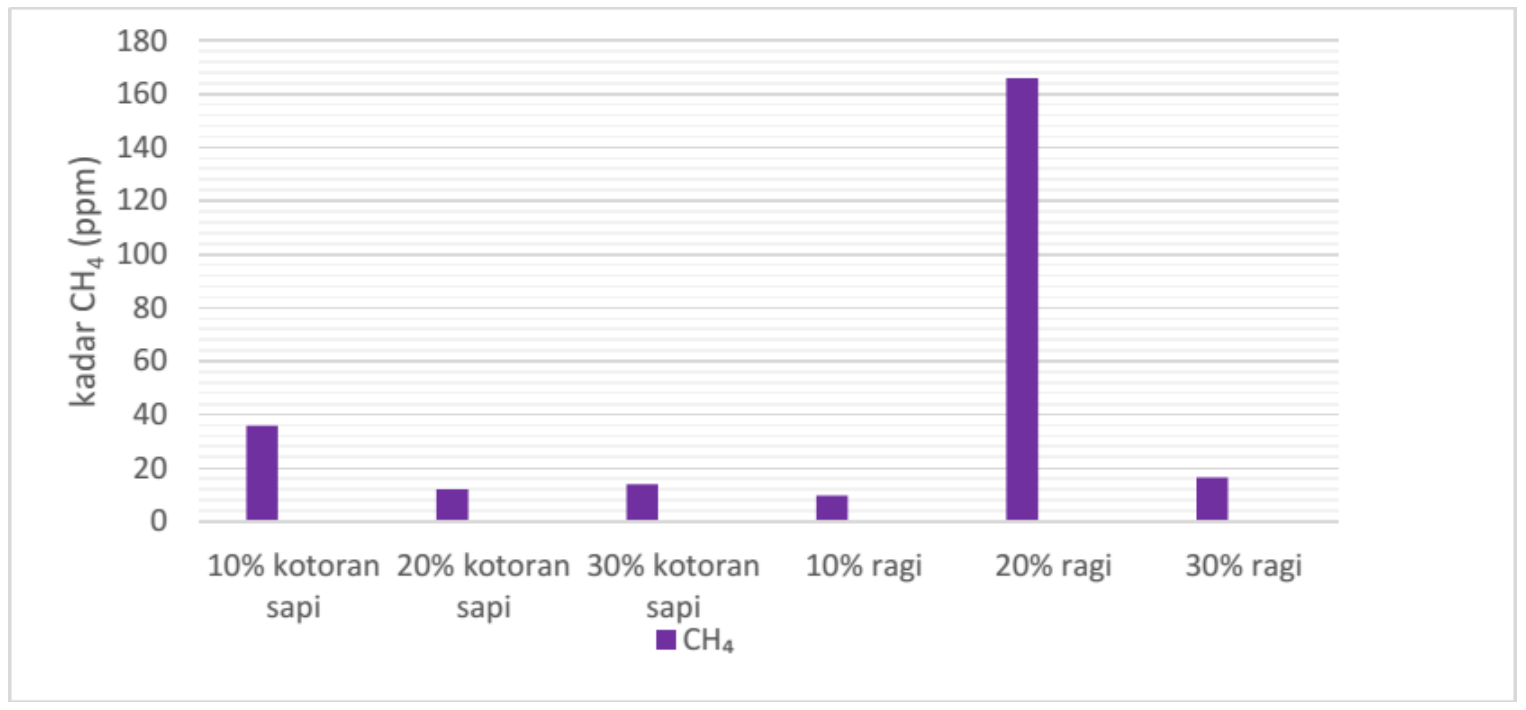

Gambar 5 Diagram Perbandingan $\mathrm{CH}_{4}$ Pada Semua Sampel Berdasarkan Pengambilan Data Dengan Waktu Yang Sama (400 detik) 
Pada diagram di atas dapat dilihat bahwa kandungan $\mathrm{CH}_{4}$ rata-rata tidak begitu tinggi, tetapi campuran $80 \%$ sampah organik dan penambahan $20 \%$ starter ragi memiliki potensi kadar biogas yang paling baik di antara sampel yang lain yaitu dengan rata-rata $166,08 \mathrm{ppm}$ ini sejalan dengan penelitian (Widyastuti, I.betanursanti, 2011) yang menyatakan bahwa produksi biogas tertinggi di peroleh pada campuran $80 \%$ loading rate dan $10 \%$ umpan. Dan untuk sampel dengan hasil terendah yaitu pada sampel dengan campuran $90 \%$ sampah organik dan $10 \%$ starter ragi yaitu 9,78 ppm. Untuk temperature di dalam biodigester pada saat fermentasi yang di dapatkan pada penelitian ini nilai optimum terdapatkan pada sampel dengan campuran $80 \%$ sampah organik dan $20 \%$ starter ragi dengan nilai temperatur $30,11^{\circ} \mathrm{C}$ sedangkan nilai minimum temperatur terdapat pada sampel dengan campuran $90 \%$ sampah organik dan $10 \%$ starter ragi yaitu $29,7^{\circ} \mathrm{C}$.

\section{3d. Perbandingan $\mathrm{CO}_{2}$ Pada Semua Sampel Berdasarkan Pengambilan Data Dengan Waktu Yang Sama}

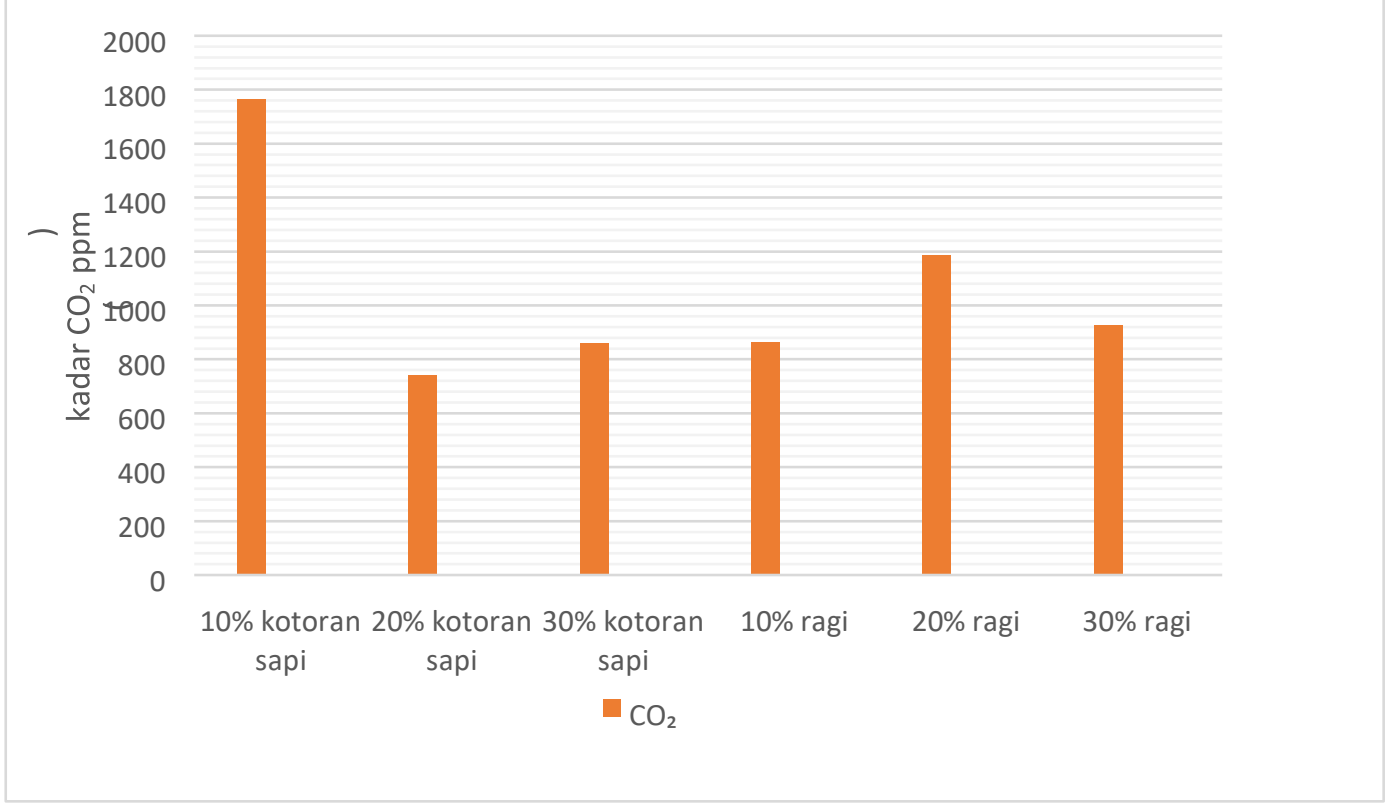

Gambar 6 Diagram Perbandingan $\mathrm{CO}_{2}$ Pada Semua Sampel Berdasarkan Pengambilan Data Dengan Waktu Yang Sama (400 detik)

Pada diagram di atas dapat di lihat bahwa kandungan $\mathrm{CO}_{2}$ rata-rata begitu tinggi berbanding terbalik dengan kadar $\mathrm{CH}_{4}$ yang rata-rata memiliki kandungan kadar $\mathrm{CH}_{4}$ yang rendah. Pada diagram di atas terlihat pada campuran $90 \%$ sampah organik dan $10 \%$ penambahan starter kotoran sapi mempunyai kandungan kadar $\mathrm{CO}_{2}$ paling tinggi. Ini disebabkan penambahan starter $10 \%$ kotoran sapi belum mampu menyeimbangi kandungan asam yang terkandung dalam limbah sampah organik, hal ini menyebabkan produksi biogas serta gas metan yang di hasilkan kurang optimal dan menghasilkan $\mathrm{CO}_{2}$ yang begitu tinggi. 


\section{3e. Pertumbuhan jamur pada proses fermentasi}

Proses fermentasi tergantung pada pertumbuhan jamur. Jamur inilah yang nanti nya akan di uraikan oleh bakteri non metanogen dan metanogen menjadi bakteri penghasil biogas. Salah satu yang sangat menentukan dalam proses pembentukan biogas yaitu ada nya peran serta bakteri, perubahan materi organik menjadi biogas ini merupakan hasil kerja macam-macam bakteri.(Bergey, 1994).

A. Pertumbuhan jamur pada waktu fermentasi campuran $90 \%$ sampah organik dan $10 \%$ starter.

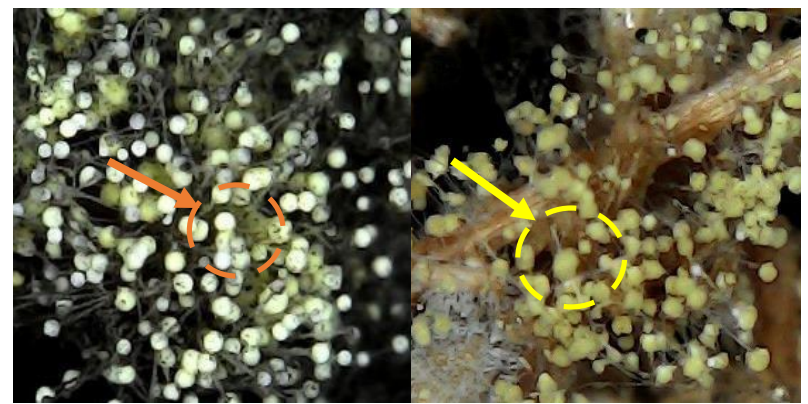

(A)

(B)

Gambar 7 Pertumbuhan jamur fermentasi 90\% sampah organik dan 10\% starter (A) starter kotoran sapi, (B) starter ragi.

Pada gambar di atas menunjukkan bahwa pertumbuhan jamur tidak terlalu subur di karena kan subsrat yang berasal tumbuhan seperti limbah pertanian banyak mengandung lignin, selulosa serta hemiselulosa yang sulit di degradasi oleh bakteri sehingga memerlukan waktu yang lebih lama untuk di konversi menjadi biogas. Sedangkan penambahan starter $10 \%$ kotoran sapi gambar 4.5 (A) dan juga ragi gambar 4.5 (B) belum mampu menyeimbangi kandungan asam yang terkandung dalam limbah sampah organik, hal ini menyebabkan produksi biogas serta gas metan yang di hasilkan kurang optimal.

B. Pertumbuhan jamur pada waktu fermentasi campuran $80 \%$ sampah organik dan $20 \%$ starter.

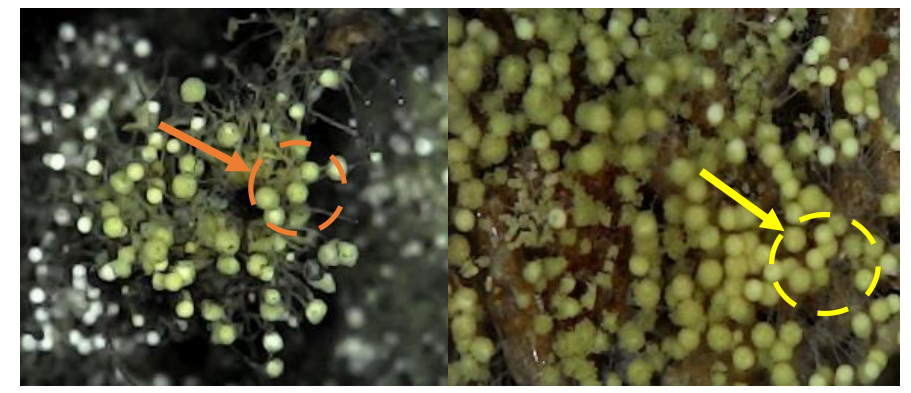

(A)

(B)

Gambar 8 Pertumbuhan jamur fermentasi $80 \%$ sampah organik dan $20 \%$ starter (A) kotoran sapi (B) ragi 
Pada gambar di atas menunjukkan bahwa pertumbuhan jamur pada gambar 4.6 (A) ditandai dengan lingkaran (orange) tidak begitu subur di karenakan penambahan $20 \%$ starter kotoran sapi belum bisa menyeimbangi kadungan asam yang terkandung dalam limbah sampah organik sehingga menyebabkan produksi biogas serta gas metan yang di hasilkan kurang optimal. Tetapi berbeda dengan penambahan $20 \%$ starter ragi pada gambar 4.6 (B) ditandai dengan lingkaran (kuning) terlihat pada gambar di atas jamur yang tumbuh cukup banyak sehingga bakteri penghasil biogas dapat bekerja dengan lebih baik dan menghasilkan kadar biogas serta gas metan yang lebih banyak dari sampel yang lain, ini sejalan dengan penelitian (Widyastuti, I.betanursanti, 2011) yang menyatakan bahwa produksi biogas tertinggi di peroleh pada campuran $80 \%$ loading rate dan $10 \%$ umpan.

C. Pertumbuhan jamur pada waktu fermentasi pada campuran $70 \%$ sampah organik dan $30 \%$ starter.

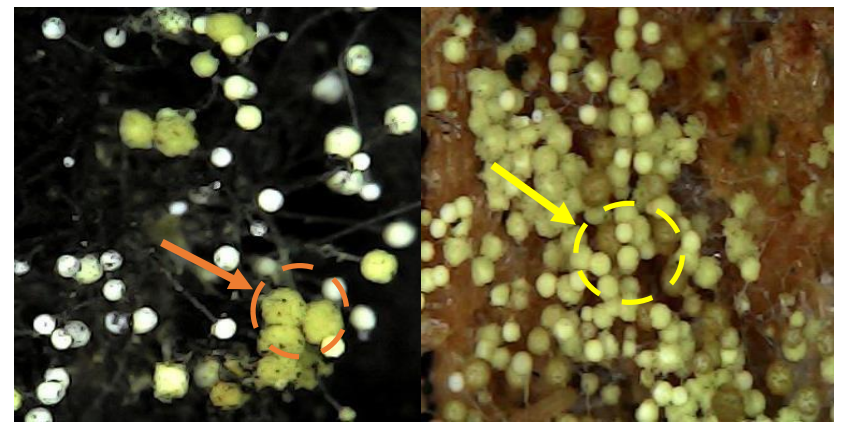

(A)

(B)

Gambar 9 Pertumbuhan jamur fermentasi 70\% sampah organik dan 30\% starter (A) kotoran sapi, (B) ragi

Pada gambar di atas menunjukkan bahwa pertumbuhan jamur pada gambar 4.7 (A) ditandai dengan lingkaran (orange) tidak begitu optimal walaupun dengan penambahan $30 \%$ starter kotoran sapi itu di sebabkan karena semakin lama waktu fermentasi juga berdampak kurang baik dalam fermentasi di mana nutrisi yang ada dalam digester semakin menipis sehingga kerja bakteri dapat terhambat yang berdampak pada produksi gas metan yang rendah. Begitu juga dengan penambahan $30 \%$ starter ragi pada gambar 4.7 (B) ditandai dengan lingkaran (kuning) terlihat sedikit lebih banyak jamur yang tumbuh di bandingkan pada gambar 4.7 (A) ditandai dengan lingkaran (orange) namun di akhir pengujian biogas yang di hasilkan juga sangat sedikit, ini di sebabkan pada fase berikutnya bakteri sudah mulai kekurangan nutrisi di mana jumlah bakteri yang tumbuh sama banyak nya dengan bakteri yang mati sehingga biogas yang di hasilkan cenderung konstan (tetap). Ini sejalan dengan penelitian (Agustina, 2011) yang menjelaskan bahwasannya pertumbuhan bakteri metanogenesis di awal proses masih mengalami masa penyesuaian dengan keadaan di dalam bahan baku yang akan di uraikan menjadi biomassa, berikutnya bakteri mengalami proses pertumbuhan yang begitu cepat sehingga akan di hasilkan produksi biogas. Fase berikutnya bakteri mulai kekurangan nutrisi di mana jumlah bakteri yang tumbuh sama banyak nya dengan bakteri yang mati 
sehingga biogas yang di hasilkan cenderung konstan (tetap). Berikutnya bakteri sudah mulai mati sehingga produksi biogas sudah mulai menurun.

\section{KESIMPULAN} berikut:

Berdasarkan hasil pada penelitian ini maka dapat di ambil kesimpulan sebagai

a. Untuk jumlah campuran starter yang menghasilkan biogas dengan kadar paling tinggi adalah $80 \%$ sampah organik dan $20 \%$ starter ragi.

b. Campuran ragi $20 \%$ dan limbah organik $80 \%$ menghasilkan $\mathrm{CH}_{4}$ yang paling optimum dengan temperatur di dalam digester pada saat fermentasi yaitu $30,11^{\circ} \mathrm{C}$ dengan nilai 206,76 ppm sedangkan pada campuran $10 \%$ starter kotoran sapi dan $90 \%$ limbah organik menghasilkan kadar $\mathrm{CO}_{2}$ paling tinggi yaitu pada temperatur $30,4^{\circ} \mathrm{C}$ dengan nilai $2527,57 \mathrm{ppm}$.

c. Untuk pertumbuhan jamur yang paling optimal adalah pada campuran $80 \%$ sampah organik dan $20 \%$ starter ragi dimana jamur yang tumbuh cukup subur sehingga menghasilkan biogas yang lebih banyak dengan nilai ratarata $\mathrm{CH}_{4} 166,08 \mathrm{ppm}$ dan $\mathrm{CO}_{2} 1185,35 \mathrm{ppm}$. Selanjutnya untuk campuran $90 \%$ sampah organik dan $10 \%$ starter kotoran sapi jamur yang dihasilkan lebih sedikit dan menghasilkan kadar $\mathrm{CH}_{4}$ dengan rata-rata 35,79 ppm dan $\mathrm{CO}_{2}$ dengan rata-rata $1763,34 \mathrm{ppm}$. Pada campuran $70 \%$ sampah organik dan $30 \%$ starter ragi jamur yang tumbuh kurang subur dibandingkan sampel sebelumnya sehingga kadar biogas yang dihasilkan pun sedikit yaitu dengan nilai rata-rata $\mathrm{CH}_{4} 16,66$ ppm dan $\mathrm{CO}_{2}$ 927,29 ppm. Pada campuran $70 \%$ sampah organik dan $30 \%$ starter kotoran sapi jamur yang tumbuh lebih sedikit dibandingkan sampel sebelumnya sehingga menghasilkan kadar biogas yang sedikit pula yaitu dengan nilai rata-rata $\mathrm{CH}_{4} 14,08$ ppm dan $\mathrm{CO}_{2} 858,87$ ppm. Pada campuran $80 \%$ sampah organik dan $20 \%$ starter kotoran sapi pertumbuhan jamur tidak tertalu subur sehingga kadar biogas yang dihasilkan pun sedikit dengan nilai rata-rata $\mathrm{CH}_{4} 12,12 \mathrm{ppm}$ dan $\mathrm{CO}_{2} 740,55$ ppm. Dan pada campuran $90 \%$ sampah organik dan $10 \%$ starter ragi jamur yang tumbuh lebih sedikit dibandingkan sampel yang lain dan menghasilkan kadar biogas yang sedikit juga yaitu dengan nilai rata-rata $\mathrm{CH}_{4} 9,78$ ppm dan $\mathrm{CO}_{2} 860,98$ ppm.

\section{DAFTAR PUSTAKA}

Dwi Irawan, Dkk. 2016. Pengaruh EM4 ( Effective Microorganism ) Terhadap Produksi Biogas Menggunakan Bahan Baku Kotoran Sapi. Fakultas Teknik, Universitas Muhammadiyah Metro.

Foot, A.s.,S.Banes, Ja.C.G. Oge, J.C. Howkins, V.C. Nielsen, And Jr.O Callaghan. 1976. Studies On Farm Livestock Waste. I" Ed. Agriculture Research Council, England.

Lateng N. 2010. Pengaruh Jumlah Biostarter Dan Waktu Fermentasi Pada Pemanfaatan Limbah Kulit Buah Kakao Sebagai Bahan Baku Pembuatan Biogas. Tesis. Program Pascasarjana. UNHAS, Makassar.

Maramba, Felix D., Sr. 1978. Biogas And Waste Recycling: The Philippine Experience. Philippine: Metro Manila Maya Farms Division-Liberty Flour Mills. 
Rahman B. 2005. Biogas Sebagai Sumber Energy Alternative, (http://www.energi.lipi.go.id/utama.cgi?cetakartikel\&1123717100).

Said D. dkk. 2006. Biogas Skala Rumah Tangga. Program Bio Energi Pedesaan (BEP). Ditjen PPHP Deptan Jakarta.

Simamora S. 2004. Makalah Pelatihan Pembuatan Pupuk Organik Yang Berkualitas Dalam Rangka Pengembangan Pertanian Terpadu Yang Berwawasan Lingkungan, Kerja Sama IPB Dan Earth University. IPB Press. Bogor.

Sufyandi A. 2001. Informasi Teknologi Tepat Guna Untuk Pedesaan Biogas, Bandung Suriawiria dan Unus H. 2002. Menuai Biogas Dari Limbah, (Http://Www.PikiranRakyat.Com/Squirrelmail).

Wahyuni S. 2011. Panduan Praktis Biogas, Penebar Swadaya, Jakarta timur. 